\title{
BUDIDAYA RUMPUT LAUT, Kappaphycus alvarezii SECARA TERINTEGRASI DENGAN IKAN KERAPU DI TELUK GERUPUK KABUPATEN LOMBOK TENGAH, NUSA TENGGARA BARAT
}

\author{
I Nyoman Radiarta, Erlania, dan Ketut Sugama \\ Pusat Penelitian dan Pengembangan Perikanan Budidaya \\ Jl. Ragunan No. 20, Pasar Minggu, Jakarta Selatan 12540 \\ E-mail: radiarta@yahoo.com
}

(Naskah diterima: 3 Februari 2014; Disetujui publikasi: 2 April 2014)

\begin{abstract}
ABSTRAK
Budidaya ikan laut dalam keramba jaring apung menghasilkan banyak sisa pakan dan feses yang dapat meningkatkan kandungan nutrien berupa nitrogen dan fosfat perairan. Pemanfaatan nutrien tersebut dapat dilakukan melalui budidaya rumput laut di sekitar keramba ikan laut. Pengamatan pertumbuhan dan laju pertumbuhan spesifik terhadap dua varietas rumput laut (Kappaphycus alvarezii var. Maumere dan Tambalang) telah dilakukan di Teluk Gerupuk, Lombok Tengah untuk satu siklus musim tanam pada bulan September-Oktober 2013. Hasil penelitian ini menunjukkan bahwa performansi pertumbuhan rumput laut yang terintegrasi dengan keramba ikan laut sangat baik. Laju pertumbuhan spesifik terbesar ditemukan pada varian Maumere yaitu berkisar antara 4,26\%-4,68\%/hari dibandingkan dengan varian Tambalang yaitu berkisar antara 3,90\%-4,20\%/hari. Secara umum melalui sistem budidaya multi-tropik terintegrasi (IMTA) ini, peningkatan produksi rumput laut dapat mencapai $74 \%$ dibandingkan dengan sistem monokultur. Model IMTA sangat relevan dengan program ekonomi biru Kementerian Kelautan dan Perikanan dalam mendukung pengembangan perikanan budidaya yang berkelanjutan.
\end{abstract}

KATA KUNCl: rumput laut, budidaya multi-tropik terintegrasi, nutrien, Teluk Gerupuk

ABSTRACT: Integrated mariculture of seaweed, Kappaphycus alvarezii, and grouper cages in Gerupuk Bay Central Lombok Regency, West Nusa Tenggara. By: I Nyoman Radiarta, Erlania, and Ketut Sugama

Marine fish farming produce large amounts of wastes that can increase dissolved inorganic phosphorous and nitrogen. Utilization of available nutrients can be done through seaweed cultivation around the marine fish cages. Observation of growth and specific growth rate of the two strains of seaweed (Kappaphycus alvarezii var. Maumere and Tambalang) was conducted in Gerupuk Bay, Central Lombok for one cycle of cultivation during September-October 2013. The results showed that the growth of seaweeds that integrated with marine fish cage was very good. The high specific growth rate was found in straint of Maumere ranging from 4.26\%-4.68\%/day compared with straint of Tambalang ranging from 3.90\%-4.20\%/day. In general through integrated multi-trophic aquaculture (IMTA) system, seaweed production could increased for about $74 \%$ compared to monoculture system. Implementation of integrated multi-trophic aquaculture (IMTA) model highly relevant to the blue economic 
program of Ministery of Marine Affair and Fisheries in order to support sustainable aquaculture development.

\section{KEYWORDS: seaweeds, integrated multi-trophic aquaculture, nutrient, Gerupuk Bay}

\section{PENDAHULUAN}

Ikan kerapu dan rumput laut merupakan komoditas industrialisasi Kementerian Kelautan dan Perikanan (KKP). Produksi ikan kerapu di Indonesia menunjukkan peningkatan yang sangat fluktuatif. Produksi ikan kerapu tahun 2002 mencapai 7.057 ton, namun pada tahun 2006 mengalami penurunan produksi yaitu 3.132 ton, dan selanjutnya menunjukkan peningkatan yang perlahan dengan produksi mencapai 8.091 tahun 2011 (DJPB, 2012). Dibandingkan dengan ikan kerapu, produksi rumput laut menunjukkan peningkatan yang sangat signifikan yaitu 4,5 juta ton di tahun 2011 dibandingkan dengan produksi tahun 2002 hanya mencapai 233 ribu ton (DJPB, 2012). Di tahun 2011 , produksi rumput laut ini memberikan kontribusi sekitar $98 \%$ dari total produksi budidaya laut di Indonesia, sedangkan ikan kerapu hanya berkontribusi sekitar 0,2\% (DJPB, 2012).

Laju perkembangan budidaya laut secara intensif sering menimbulkan dampak negatif berupa penurunan mutu lingkungan perairan (Beveridge, 1996; Costa-Pierce, 2008). Dampak kegiatan budidaya terhadap lingkungan harus diminimalkan atau bahkan dapat dihilangkan. Oleh sebab itu, segala kegiatan budidaya perikanan harus berwawasan lingkungan sehingga aktivitas budidaya perikanan tersebut dapat berkelanjutan. Dampak yang paling terlihat dari budidaya ikan laut dalam keramba jaring apung (KJA) adalah adanya sisa pakan yang terurai dalam kolom air yang dapat meningkatkan biochemical oxygen demand, meningkatkan kandungan fosfat terlarut dan meningkatkan kandungan nitrogen terlarut (Troell et al., 1997). Secara umum hanya sekitar 30\% nutrien yang berasal dari pakan termanfaatkan oleh ikan, dan sisanya akan terlepas ke perairan dalam bentuk sisa pakan dan feses (Beveridge, 1996; Troell et al., 1997; Rachmansyah et al., 2004), namun hal ini bergantung daripada kualitas pakan yang diberikan dan manajemen budidaya yang diterapkan.

Ketersediaan nutrien dalam perairan yang berasal dari aktivitas budidaya ikan dalam
KJA sebagian dapat dimanfaatkan melalui budidaya rumput laut. Ketersediaan dissolved inorganic nutrient (DIN) yang berasal dari KJA ikan akan mendukung secara positif perkembangan dan pertumbuhan rumput laut yang dibudidayakan (Troell et al., 1997; Chopin et al., 2001; Sanderson et al., 2008). Melalui penempatan unit budidaya rumput laut pada kisaran jarak tertentu dengan KJA ikan selain meningkatkan produktivitas budidaya juga dapat mengurangi pengkayaan nutrien dalam kolom air yang dapat berdampak pada terjadinya eutrofikasi. Model pengembangan budidaya secara terintegrasi ini dikenal dengan integrated multi-trophic aquaculture/ IMTA (Barrington et al., 2009). IMTA adalah budidaya terintegrasi antara beberapa komoditas yang memiliki tingkat tropik yang berbeda dalam hal pemanfaatan sumber makanan (energi) dalam perairan meliputi komoditas yang diberikan pakan yaitu ikan dengan dengan komoditas yang dapat mengekstrak dissolved inorganic nutrients (rumput laut) atau particulate organic matter (kekerangan), sehingga terjadi keseimbangan antara proses biologi dan kimia pada sistem yang berkembang. IMTA merupakan opsi pengembangan budidaya perikanan ke depan. Hal ini disebabkan karena selain dapat meningkatkan produksi dari beberapa komoditas secara simultan juga dapat meminimalkan dampak negatif terhadap lingkungan perairan. Penerapan IMTA sangat fleksibel dan dapat diterapkan di perairan terbuka atau unit budidaya di daratan baik itu di perairan tawar atau laut, bahkan pengembangan IMTA juga sudah menyebar sampai pada lautan terbuka (Troell et al., 2009). Yang paling utama dalam penerapan IMTA adalah pemilihan komoditas sesuai dengan fungsinya dalam suatu ekosistem dan juga memperhatikan nilai jual komoditas tersebut. Model pengembangan budidaya berbasis IMTA sangat relevan dengan program ekonomi biru Kementerian Kelautan dan Perikanan (KKP), yang mana dapat meningkatkan produksi secara maksimal tanpa merusak lingkungan budidayanya (zero waste) sehingga dapat menuju pengembangan perikanan budidaya yang berkelanjutan. Pene- 
litian ini bertujuan untuk menganalisis pertumbuhan rumput laut yang dibudidayakan secara terintegrasi (IMTA) dengan ikan kerapu dan melihat karakteristik nutrien perairan di sekitar kawasan IMTA di Teluk Gerupuk, Lombok Tengah.

\section{BAHAN DAN METODE}

Penelitian telah dilaksanakan pada bulan September-Oktober 2013 di Teluk Gerupuk Kabupaten Lombok Tengah, Nusa Tenggara Barat (Gambar 1). Teluk Gerupuk dengan luasan sekitar 814 ha, sangat berpotensi untuk pengembangan budidaya laut. Perairan ini telah dimanfaatkan untuk berbagai aktivitas di antaranya perikanan budidaya (ikan, lobster, dan rumput laut), perikanan tangkap, dan pariwisata (surfing). Luasan potensial untuk pengembangan budidaya rumput laut mencapai 322 ha (Radiarta \& Rasidi, 2012). Kawasan pengembangan budidaya rumput laut umumnya terletak di tengah-tengah teluk dengan karakteristik perairan yang cukup bersih (jauh dari sedimentasi), arus yang memadai dan gelombang yang tidak terlalu besar.

Model IMTA yang diterapkan di lokasi penelitian merupakan integrasi antara ikan kerapu dan rumput laut (Gambar 1B). Jenis ikan yang digunakan sebagai komoditas utama dari sistem budidaya ini adalah ikan kerapu cantang (Epinephelus sp.) yang merupakan jenis kerapu hibrid hasil perkawinan silang antara ikan kerapu macan (Epinephelus fuscoguttatus) sebagai induk betina dengan kerapu kertang (E. lanceolatus) sebagai induk jantan. Ikan kerapu dibudidayakan pada empat lubang KJA
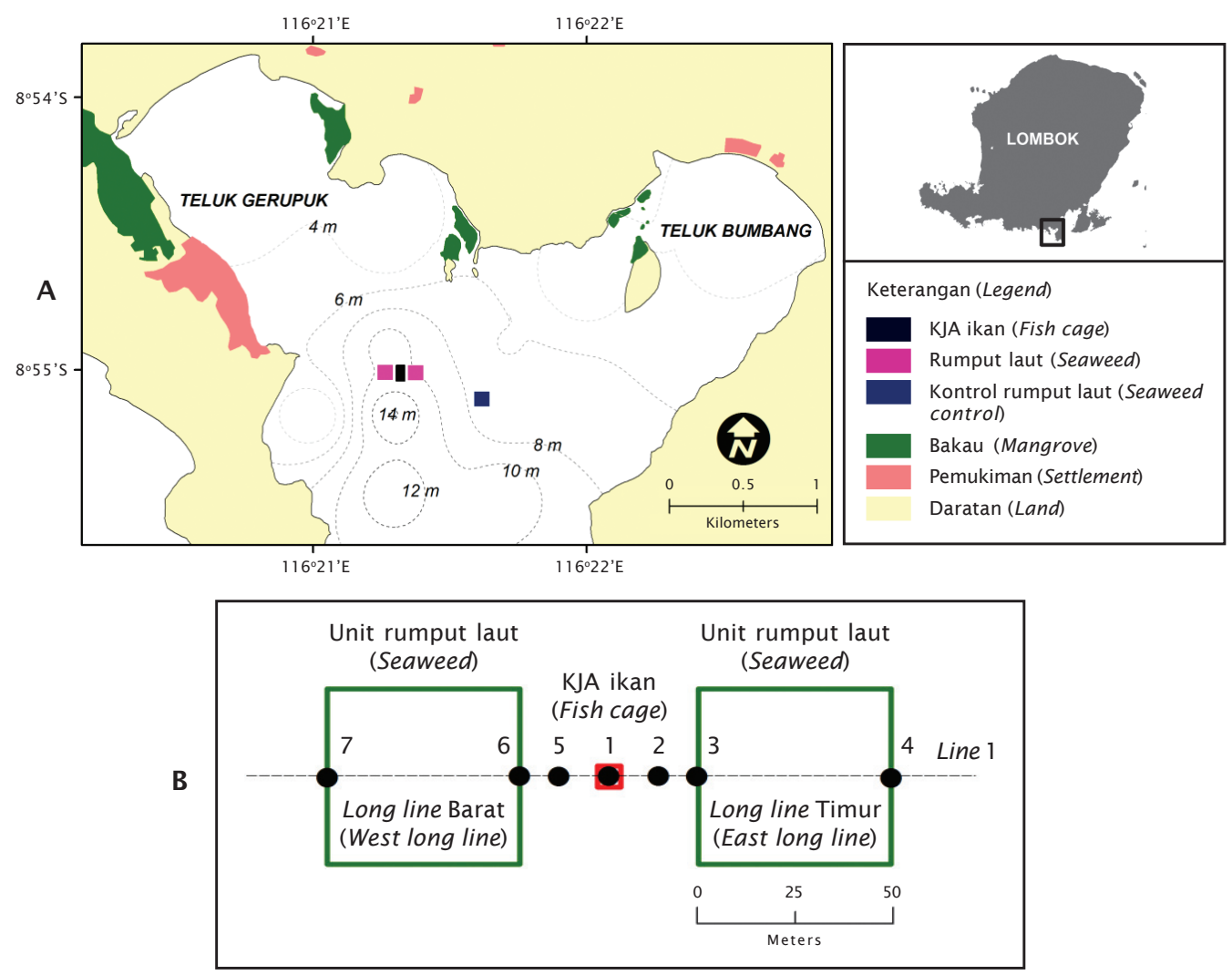

Gambar 1. Lokasi penelitian di Teluk Gerupuk, Lombok Tengah yang menampilkan posisi unit IMTA (A) dan desain IMTA (B). Angka menunjukkan titik pengambilan data kualitas perairan dan line 1 adalah lokasi analisis kualitas perairan secara stratifikasi

Figure 1. The study area in Gerupuk Bay, Central Lombok that shows integrated multi-trophic aquaculture (IMTA) unit (A) and IMTA design (B). Numbers indicate water quality sampling stations and line 1 was used for vertical water quality analysis 
dengan ukuran $3 \mathrm{~m} \times 3 \mathrm{~m} \times 3 \mathrm{~m}$. Setiap lubang KJA diisi sebanyak 500 ekor dengan bobot awal ikan adalah sekitar $31,57 \pm 3,77 \mathrm{~g}$. Komoditas selanjutnya adalah rumput laut. Terdapat dua varian rumput laut yang dibudidayakan pada penelitian ini, yaitu Kappaphycus alvarezii var. Maumere dan Tambalang (cottonii). Rumput laut dibudidayakan dengan sistem long line; yang terdiri atas tiga unit long line masing-masing berukuran $50 \mathrm{~m} \times 50 \mathrm{~m}$. Unit long line-1 dan long line-2 ditempatkan pada jarak sekitar 20 m sebelah Barat dan Timur budidaya ikan dengan keramba jaring apung (KJA); sedangkan long line-3 yang merupakan long line kontrol terletak sekitar $550 \mathrm{~m}$ ke arah luar teluk (Gambar 1). Satu unit long line terdiri atas 25 bentangan tali ris dan setiap tali ris terdiri atas 250 titik tanam/ikatan rumput laut, dan tiap titik tanam berjarak sekitar $20 \mathrm{~cm}$. Bibit rumput laut diikatkan sepanjang tali ris dengan bobot sekitar 100 g/titik tanam (SNI 7579.2:2010; BBL, 2012). Pengamatan pertumbuhan rumput laut dilakukan setiap 15 hari sekali, dengan mengukur bobot dari contoh rumput laut. Sebanyak lima titik contoh rumput laut yang diambil secara acak $(n=5)$ dari setiap varian rumput laut pada ketiga unit long line selama budidaya dilakukan yaitu 45 hari.

Selain data performansi pertumbuhan, kondisi kualitas perairan yang berhubungan dengan sisa pakan yang terurai dalam bentuk DIN yang dapat dimanfaatkan oleh rumput laut juga diamati (Barrington et al., 2009). Sebanyak tujuh titik pengamatan kualitas perairan disebar di sekitar unit IMTA (Gambar 1B). Pengamatan kualitas perairan dilakukan secara stratifikasi pada tiga kedalaman yaitu permukaan $(0 \mathrm{~m}), 3 \mathrm{~m}$, dan dasar. Parameter yang diamati meliputi nitrit $\left(\mathrm{NO}_{2}-\mathrm{N}\right)$, amoniak $\left(\mathrm{NH}_{3}-\mathrm{N}\right)$ dan fosfat $\left(\mathrm{PO}_{4}-\mathrm{P}\right)$. Contoh air diambil setiap bulan untuk dianalisis di Laboratorium Pengujian Balai Budidaya Laut Lombok. Metode pengambilan, preservasi, dan analisis contoh air mengacu pada metode standar APHA (2005).

\section{Analisis Data}

Rumput laut yang dibudidayakan dihitung laju pertumbuhan spesifik (specific growth rate/SGR) dengan rumus (Effendie, 1979; Neori et al., 2000):

$$
\operatorname{SGR}(\%)=\frac{\ln W \mathrm{t}-\mathrm{Ln} \mathrm{Wo}_{0}}{\mathrm{t}} \times 100 \%
$$

di mana:

Wt adalah bobot basah akhir pemeliharaan (g), Wo adalah bobot basah awal pemeliharaan $(\mathrm{g})$ dan $\mathrm{t}$ adalah lama pemeliharaan (hari).

Sedangkan produksi (P) rumput laut di hitung dengan rumus:

$$
\mathrm{P}(\mathrm{kg} / \mathrm{ha})=\{(\mathrm{W} \times 1,000) \times \mathrm{J} \times \mathrm{L}\} \times 4
$$

di mana:

W adalah bobot rata-rata akhir pemeliharaan (g), J adalah jumlah titik dalam satu line (250 titik), $\mathrm{L}$ adalah jumlah line dalam satu unit (25 line) parameter pengamatan. Analisis statistik ANOVA single factor juga dilakukan untuk melihat ada tidaknya perbedaan antara budidaya rumput laut dengan sistem IMTA dan kontrol/monokultur.

Data kualitas air yang dikumpulkan dianalisis secara spasial yang ditampilkan secara vertikal. Perangkat lunak yang digunakan dalam analisis ini adalah Ocean Data View (ODV). Untuk melakukan analisis spasial, seluruh data yang terkumpul diinterpolasi dengan teknik VG gridding (Schlitzer, 2011).

\section{HASIL DAN BAHASAN}

\section{Pertumbuhan Rumput Laut}

Secara umum, rumput laut yang dibudidayakan dengan sistem IMTA memperlihatkan pertambahan bobot yang relatif lebih besar dan cenderung tumbuh lebih baik (meningkat dari awal hingga akhir masa pemeliharaan) jika dibandingkan dengan rumput laut kontrol (Gambar 2). Hal ini dapat dijadikan indikasi awal terjadinya ekspos nutrien yang berasal dari limbah KJA terhadap rumput laut yang dibudidayakan di sekitar KJA tersebut. Menurut Neori et al. (2000), ide yang tergambar dari kondisi budidaya dengan sistem IMTA ini yaitu tingginya pertumbuhan rumput laut didukung oleh terdapatnya amoniak yang diekskresikan oleh ikan ke lingkungan; selain itu, rumput laut juga berperan dalam memfiltrasi amoniak dari lingkungan perairan.

Pertumbuhan rata-rata dari kedua varietas rumput laut yang dibudidayakan yaitu Kappaphycus alvarezii var. Maumere dan Tambalang menunjukkan bahwa jenis $K$. alvarezii varietas Maumere memiliki laju pertumbuhan yang lebih tinggi dibandingkan $K$. alvarezii varietas Tambalang, dengan bobot akhir rata-rata $628 \mathrm{~g}$ dan $822 \mathrm{~g}$ untuk long line Barat dan Timur. Bobot tersebut jauh lebih besar dibandingkan dengan long line kontrol 

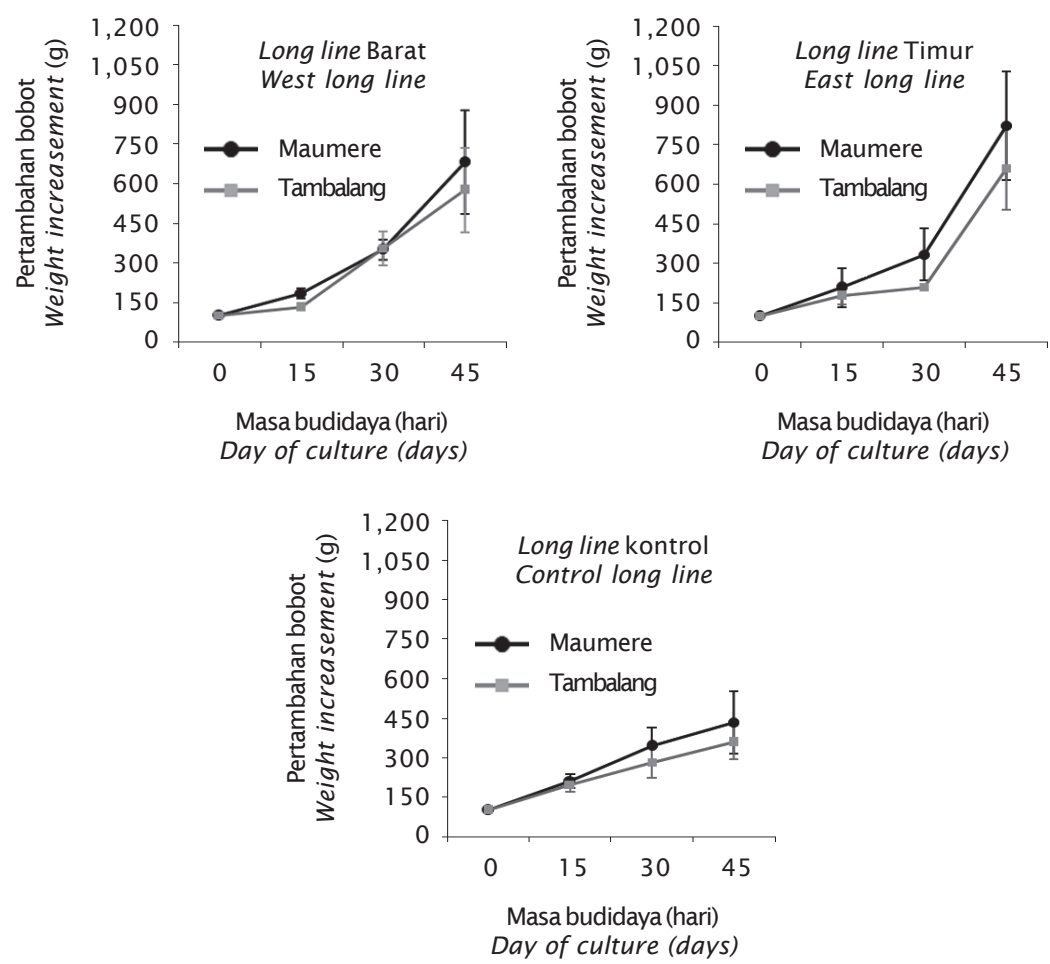

Gambar 2. Pertumbuhan rata-rata rumput laut antara budidaya terintegrasi (IMTA) dan kontrol di Teluk Gerupuk, Lombok Tengah. Lokasi long line rumput laut dapat dilihat pada Gambar 1

Figure 2. Average growth of seaweed between IMTA system and control in Gerupuk Bay, Central Lombok. Position of seaweed units are shown in Figure 1

yaitu 433 g (Gambar 2). Adanya perbedaan bobot akhir rumput laut dari hasil penelitian ini mengindikasikan bahwa dispersi nutrien dari KJA ke dalam perairan cukup berbeda bergantung dari posisi penempatan unit rumput laut tersebut (Barat, Timur dan kontrol). Hasil serupa juga ditemukan oleh Troell et al. (1997) pada penempatan unit Gracilaria chilensis di sekitar KJA ikan salmon di perairan Puerto Montt, Chile. Pertumbuhan Gracilaria chilensis pada jarak 10 m dari KJA memberikan pertumbuhan yang lebih tinggi daripada jarak $150 \mathrm{~m}$ dan $1 \mathrm{~km}$ dari KJA. Hal ini didukung oleh adanya kandungan nutrien yang tinggi pada lokasi dekat dengan KJA (Troell et al., 1997).

Laju pertumbuhan spesifik rumput laut hasil budidaya dengan IMTA dan kontrol disajikan pada Gambar 3. Rumput laut K. alvarezii varietas Maumere memiliki laju pertumbuhan spesifik yang lebih baik yaitu berkisar antara 4,26\%-4,68\%/hari dibandingkan dengan varietas Tambalang yaitu berkisar antara 3,90\%$4,20 \% /$ hari. Pada budidaya rumput laut di unit kontrol hanya memberikan laju pertumbuhan spesifik berkisar antara 2,83\%-3,26\%/hari untuk dua jenis varian rumput laut (Gambar 3). Berdasarkan lokasi penempatan long line budidaya rumput laut menunjukkan bahwa long line yang ditempatkan di sebelah Timur KJA menghasilkan laju pertumbuhan spesifik yang lebih tinggi dibandingkan dengan long line di sebelah Barat KJA, dengan kisaran nilai masingmasing 4,20\%-4,68\%/hari dan 3,90\%-4,27\%/hari (Gambar 3). Hasil analisis ANOVA menunjukkan bahwa terdapat perbedaan yang signifikan pada laju pertumbuhan spesifik antara long line Timur $(\mathrm{P}<0,05)$ dan long line Barat $(\mathrm{P}<0,01)$ dengan long line kontrol.

Laju pertumbuhan spesifik yang diperoleh dari hasil penelitian ini menunjukkan hasil yang lebih baik dibandingkan dengan hasil penelitian di Filipina untuk jenis yang sama yaitu Kappaphycus alvarezii (Hurtado et al., 2001). Laju pertumbuhan spesifik yang tertinggi diperoleh oleh Hurtado et al. (2001) selama masa pemeliharaan yaitu pada bulan Januari-Februari 


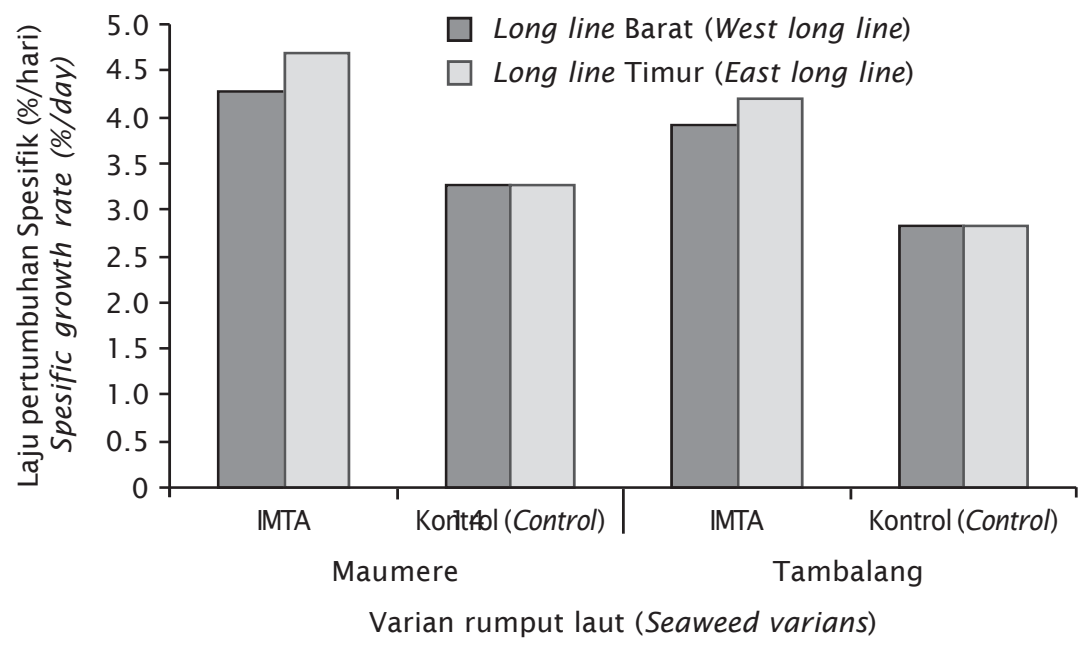

Gambar 3. Laju pertumbuhan spesifik (\%/hari) dua varietas rumput laut pada unit IMTA dan kontrol di Teluk Gerupuk, Lombok Tengah

Figure 3. Specific growth rate (\%/day) of two seaweed straints at the IMTA unit and control in Gerupuk Bay, Central Lombok

dengan berkisar antara 2,3\%-4,2\%/hari. Hal ini menunjukkan bahwa perairan di Teluk Gerupuk sangat mendukung untuk pengembangan budidaya rumput laut. Selain itu, faktor waktu dan tempat pemeliharaan akan sangat memengaruhi produktivitas rumput laut (Hurtado et al., 2001; Radiarta et al., 2013).

Hasil perhitungan pertumbuhan dan laju pertumbuhan spesifik yang diperoleh dari penelitian ini hanya memberikan gambaran sesaat, karena penelitian hanya dilakukan pada satu siklus musim tanam rumput laut. Perhitungan yang lebih komprehensif dengan memperpanjang masa pemeliharaan (siklus) tentunya akan memberikan gambaran yang lebih baik mengenai performansi pertumbuhan rumput laut yang dibudidayakan.

\section{Kondisi Nutrien Perairan}

Nutrien dan ketersediaan cahaya matahari merupakan faktor utama yang memengaruhi pertumbuhan dan produktivitas budidaya rumput laut (Sanderson et al., 2008; Troell et al., 2009). Rumput laut yang dibudidaya di lokasi penelitian telah mengikuti standar operasi pengembangan rumput laut (BBL, 2012) dengan menggunakan sistem rawai (long line). Sesuai dengan standar operasi tersebut, rumput laut umumnya ditanam pada kedalaman $30 \mathrm{~cm}$ dari permukaan air. Hal ini menunjukkan bahwa unit rumput laut tersebut akan menerima intensitas cahaya yang sama, sehingga ketersediaan cahaya dapat dikatakan bukan faktor penghambat pertumbuhan. Sebaliknya, ketersediaan nutrien akan menjadi faktor penentu pertumbuhan rumput laut. Empat elemen utama yang dibutuhkan oleh tumbuhan akuatik untuk pertumbuhannya adalah oksigen, karbon, nitrogen, dan fosfor, dengan rasio O:C:N:P pada air laut adalah 212:106:15:1 (Davis, 1977 dalam Dawes, 1981). Senyawa nitrogen yang umumnya ditemukan pada air laut adalah $\mathrm{NO}_{3}, \mathrm{NO}_{2}$, dan $\mathrm{NH}_{3}$ yang konsentrasinya semakin menurun dengan bertambahnya kedalaman perairan; pada alga merah makroskopik ditunjukkan bahwa terdapatnya hubungan antara laju pertumbuhan dengan bentuk dan konsentrasi senyawa nitrogen (Dawes, 1981). Parameter yang berhubungan dengan ketersediaan nutrien di sekitar unit IMTA disajikan pada Gambar 4.

Di perairan alami, nitrit ditemukan dalam jumlah sangat sedikit, karena bersifat tidak stabil dengan keberadaan oksigen; nitrit merupakan senyawa peralihan (intermediate) antara amonia dan nitrat pada proses nitrifikasi, dan antara nitrat dan gas nitrogen pada proses denitrifikasi (Effendi, 2003). Oleh karena itu, sebaran vertikal parameter nitrit akan dipengaruhi oleh konsentrasi oksigen terlarut, di samping faktor-faktor lainnya. Sebaran vertikal nitrit pada lokasi penelitian pada bulan September relatif tinggi pada bagian Barat KJA 

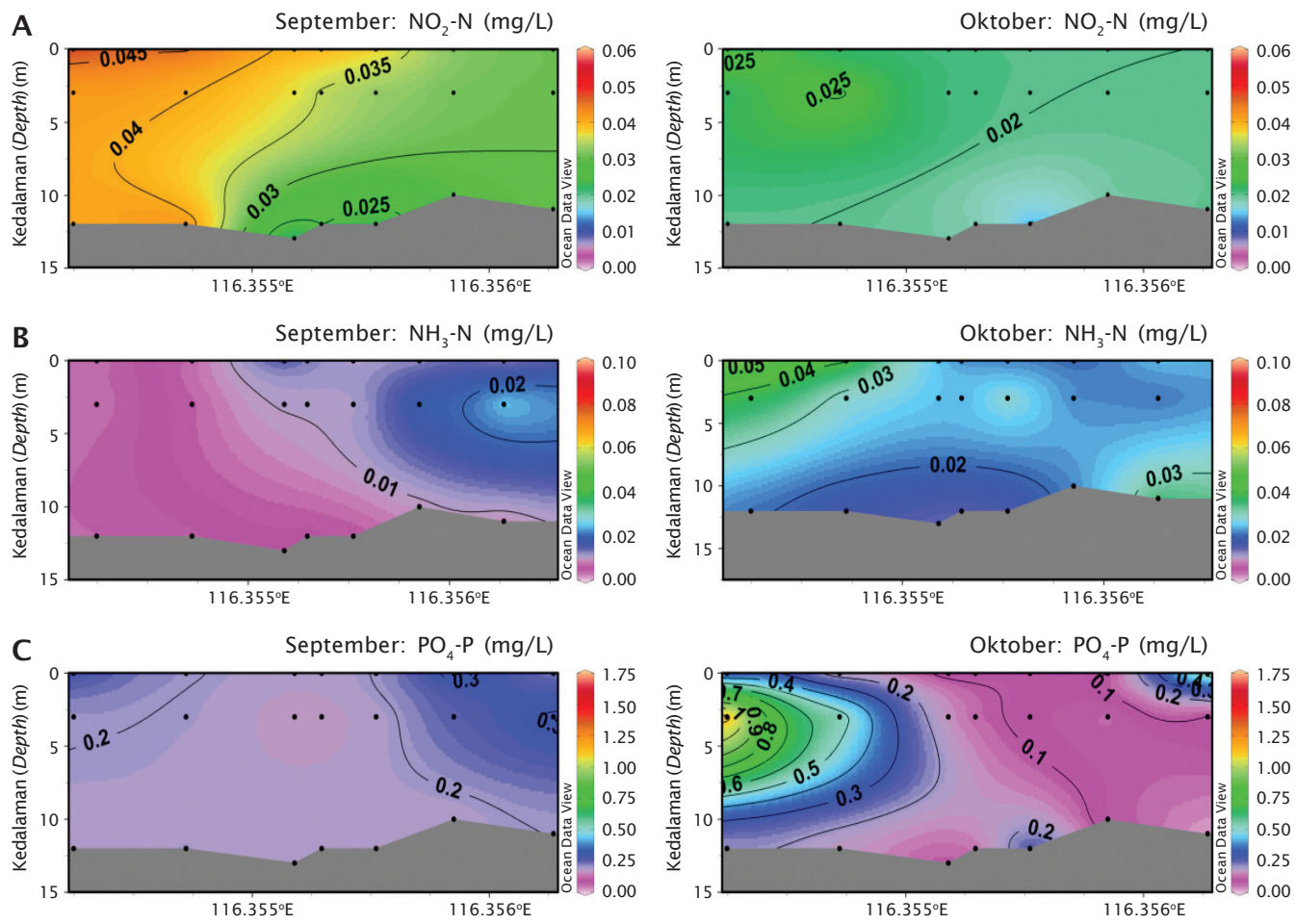

Gambar 4. Sebaran vertikal nitrit (A), amoniak (B), dan fosfat (C) bulan September-Oktober pada stasiun pengamatan unit IMTA di Teluk Gerupuk, Lombok Tengah. Stasiun pengamatan disajikan pada Gambar 1B

Figure 4. Vertical distribution of nitrite (A), ammonia (B), and phosphate (C) from SeptemberOctober at the IMTA sampling stasiun in Gerupuk Bay, Central Lombok. Samplings position show in Figure $1 B$

yang menyebar sampai pada dasar perairan. Bulan Oktober konsentrasi nitrit juga tinggi di bagian Barat KJA namun hanya pada permukaan (Gambar 4A). Nilai parameter nitrit pada lokasi penelitian dari bulan September antara 0,01-0,06 mg/L; dan bulan Oktober berkisar antara 0,01-0,03 mg/L. Kadar nitrit di perairan sebaiknya tidak lebih dari $0,06 \mathrm{mg} / \mathrm{L}$ karena akan bersifat toksik terutama terhadap organisme akuatik yang sangat sensitif (Moore, 1991 dalam Effendi, 2003; KLH, 2004).

Amonia merupakan salah satu bentuk nutrien anorganik yang dapat dimanfaatkan oleh rumput laut. Pada bulan September (awal budidaya), nilai parameter amonia relatif tinggi di sekitar KJA dan menyebar sampai pada lokasi unit budidaya rumput laut yang berada di Timur KJA dari lapisan permukaan hingga dasar perairan (Gambar 4B). Pada bulan Oktober sebaran amonia cenderung bergerak ke bagian Barat KJA dengan konsentrasi yang relatif lebih tinggi dibandingkan pada bulan September (Gambar 4B). Pada bulan ini konsentrasi amonia yang tinggi tersebar pada kedalaman kurang dari $5 \mathrm{~m}$. Kisaran nilai amonia pada bulan September yaitu 0,001-0,047 mg/L; sedangkan pada bulan Oktober berkisar antara 0,001$0,082 \mathrm{mg} / \mathrm{L}$. Konsentrasi amonia pada lokasi penelitian ini masih tergolong rendah. Nilai baku mutu kandungan amonia perairan untuk biota laut berdasarkan KEPMENLH No. 51 Tahun 2004 adalah 0,3 mg/L (KLH, 2004).

Secara umum, sumber nitrogen yang paling penting untuk makroalga adalah amonium $\left(\mathrm{NH}_{4}{ }^{+}\right)$dan nitrat $\left(\mathrm{NO}_{3}{ }^{-}\right)$, namun tidak semua makroalga dapat tumbuh sama baiknya dengan kedua bentuk sumber nitrogen tersebut (Hanisak, 1983). Hasil penelitian tentang penyerapan nitrogen oleh berbagai jenis alga dari air mengindikasikan bahwa alga pada umumnya lebih menyukai senyawa nitrogen dalam bentuk nitrat, tapi alga dapat juga me- 
manfaatkan nitrit atau amonia sebagai sumber nutrien (Dawes, 1981). Penelitian terhadap salah satu spesies chlorophyta yaitu Codium fragile, menunjukkan pertumbuhan yang sama baiknya dengan sumber nitrogen dalam bentuk $\mathrm{NO}_{2}$ - dengan $\mathrm{NO}_{3}^{-}$maupun $\mathrm{NH}_{4}^{+}$; sedangkan Goniotrichum elegans dan Nemalion multifidum dapat tumbuh lebih baik dengan sumber nitrogen dalam bentuk $\mathrm{NO}_{2}$ dibandingkan $\mathrm{NO}_{3}$. (Hanisak, 1983).

Fosfat merupakan bentuk fosfor yang dapat dimanfaatkan oleh tumbuhan (Dugan, 1972 dalam Effendi, 2003) yang merupakan unsur esensial bagi alga. Secara umum, parameter fosfat menyebar pada lapisan permukaan perairan. Pada bulan September konsentrasi fosfat yang cukup tinggi ditemui di sebelah Timur KJA, sedangkan bulan Oktober konsentrasi yang rekatif tinggi ditemui di sebelah Timur KJA pada kedalaman sekitar $5 \mathrm{~m}$ (Gambar 4C). Kisaran nilai parameter fosfat pada lokasi penelitian dari bulan SeptemberOktober yaitu 0,03-1,59 mg/L. Pada air laut, senyawa fosfor anorganik berada dalam bentuk $\mathrm{H}_{2} \mathrm{PO}_{4}$ dan $\mathrm{HPO}_{4}{ }^{2-}$ (Dawes, 1981). Tumbuhan akuatik umumnya memanfaatkan ortofosfat sebagai sumber fosfor (Effendi, 2003; Dawes, 1981). Effendi (2003) juga menyatakan bahwa pada saat perairan mengandung fosfor dalam jumlah cukup, alga akan mengakumulasi fosfor di dalam sel melebihi kebutuhannya (luxury consumption), dan kelebihan tersebut akan dimanfaatkan pada saat perairan mengalami defisiensi fosfor sehingga alga masih dapat tumbuh selama beberapa waktu. Namun pada perairan laut, biasanya fosfor bukan merupakan faktor pembatas pertumbuhan.

Hasil karakteristik sebaran nutrien di sekitar unit IMTA menunjukkan pola sebaran nutrien yang relatif seimbang antara sisi Barat dan Timur (Gambar 4). Kondisi tersebut dipengaruhi oleh karakteristik arus di lokasi penelitian, yang umumnya merupakan arus pasang surut yang banyak dipengaruhi oleh kondisi gelombang dan kecepatan angin. Ketersediaan nutrien pada kedua sisi unit budidaya rumput laut ini sangat mendukung pertumbuhan budidaya rumput laut dari dua varian rumput laut yang dibudidayakan.

\section{Perspektif Pengembangan Budidaya Laut Terintegrasi}

Budidaya laut secara terintegrasi antara beberapa komoditas sangat sesuai dengan program ekonomi biru Kementerian Kelautan dan Perikanan (KKP, 2012). Perkembangan kegiatan budidaya laut dengan konsep nirlimbah secara praktis sangat penting baik untuk kegiatan budidaya itu sendiri maupun bagi lingkungan perairan pantai (Neori et al., 2000). Sistem budidaya terintegrasi atau IMTA merupakan sistem budidaya yang didesain untuk mengurangi permasalahan lingkungan perairan yang disebabkan oleh dampak penggunaan pakan dalam kegiatan budidaya (Abreu et al., 2009; Barrington et al., 2009; Troell, 2009). Berbagai hasil penelitian menyebutkan bahwa budidaya ikan dalam KJA secara intensif akan menghasilkan limbah yang terbuang dan secara nyata memengaruhi kualitas air (Loya \& Kramarsky-Winter, 2003). Dengan budidaya terintegrasi tersebut, limbah yang dihasilkan dari KJA ikan dapat dimanfaatkan oleh biota dengan tingkat tropik yang berbeda di antaranya kekerangan dan rumput laut. Penelitian yang dilakukan baik pada sistem IMTA di darat maupun di laut telah menunjukkan bahwa nutrien yang berasal dari sisa pakan dari komoditas budidaya (ikan) adalah sangat berguna bagi pertumbuhan rumput laut (Neori et al., 2000; Neori, 2007; Troell et al., 2009). Dengan sistem IMTA ini hasil yang diperoleh juga akan meningkat karena merupakan produksi gabungan dari beberapa komoditas yang dibudidayakan.

Implementasi sistem IMTA yang diterapkan di Teluk Gerupuk menunjukkan produksi dan peningkatan produksi yang sangat signifikan dibandingkan dengan kontrol/monokultur (Tabel 1). Perhitungan produksi rumput laut untuk dua varian menunjukkan hasil yang sangat baik yaitu berkisar antara 15,5-18,8 ton/ha dibandingkan dengan kontrol yang produksinya hanya mencapai 8,9-10,8 ton/ha. Melalui sistem IMTA ini, peningkatan produksi rumput laut sangat signifikan yaitu meningkat sekitar $74 \%$. Beberapa hasil penelitian telah menunjukkan hasil yang signifikan dari produksi rumput laut dengan sistem IMTA (Troell et al., 1997; Shi et al., 2013). Berdasarkan hasil penelitian Troell et al. (1997) menunjukkan bahwa penerapan sistem IMTA dan non IMTA (monoculture) untuk budidaya rumput laut, Gracilaria chilensis, memberikan hasil yang sangat berbeda nyata. Kombinasi antara Gracilaria chilensis dan ikan salmon menghasilkan produksi sebesar 34 ton rumput laut kering/ha, sedangkan sistem monokultur Gracilaria chilensis hanya menghasilkan 16 ton rumput laut kering/ha. Hasil yang diperoleh dari penelitian ini sesuai dengan 
Tabel 1. Produksi dan peningkatan produksi rumput laut antara IMTA dan kontrol yang diterapkan di Teluk Gerupuk, Lombok Tengah

Table 1. Production and its increasement between IMTA system and control that was implemented in Gerupuk Bay, Central Lombok

\begin{tabular}{lccccc}
\hline \multirow{2}{*}{$\begin{array}{c}\text { Komoditas budidaya } \\
\text { Aquacult ure commodities }\end{array}$} & \multicolumn{2}{c}{$\begin{array}{c}\text { Produksi } \\
\text { Production }\end{array}$} & & \multicolumn{2}{c}{$\begin{array}{c}\text { Peningkatan produksi } \\
\text { Production increasement }\end{array}$} \\
\cline { 2 - 3 } \cline { 5 - 6 } & IMTA & Kont rol (Control) & & kg/ha & $\%$ \\
\hline K. alvarezii var. Maumere & 18,819 & 10,837 & & 7,983 & 73.67 \\
K. alvarezii var. Tambalang & 15,482 & 8,928 & & 6,554 & 73.40 \\
\hline
\end{tabular}

pernyataan Neori et al. (2000) bahwa multikomoditas yang dibudidayakan dengan sistem IMTA memberikan hasil produksi yang lebih baik dibandingkan dengan budidaya komoditas dengan sistem monokultur. Namun nilai positif yang lebih besar lagi dari sistem budidaya IMTA selain peningkatan nilai produksi budidaya, yaitu kualitas lingkungan perairan yang relatif lebih baik dan peluang keberlanjutan usaha budidaya yang lebih menjanjikan.

\section{KESIMPULAN}

Budidaya ikan laut yang dilakukan telah banyak memberikan dampak pada lingkungan sekitar salah satunya berupa pengkayaan nutrien. Ketersediaan nutrien yang berasal dari sisa pakan dan feses ikan dalam perairan dapat dimanfaatkan oleh komoditas lainnya yaitu rumput laut. Hasil dari penelitian ini yang dilakukan dalam satu siklus budidaya rumput laut secara terintegrasi (IMTA) dengan ikan kerapu telah menunjukkan secara signifikan tingkat pertumbuhan dan laju pertumbuhan spefisik rumput laut lebih tinggi dibandingkan dengan budidaya monokultur. Melalui sistem IMTA ini, peningkatan produksi rumput laut sangat signifikan yaitu sekitar $74 \%$. Penerapan sistem budidaya IMTA ini memberikan nilai positif yaitu selain peningkatan nilai produksi budidaya, juga kualitas lingkungan perairan yang relatif lebih baik dan peluang keberlanjutan usaha budidaya yang lebih menjanjikan.

\section{UCAPAN TERIMA KASIH}

Penulis mengucapkan terima kasih kepada Balai Budidaya Laut Lombok di Sekotong dan di Gerupuk atas bantuannya selama kegiatan lapangan. Terutama kepada Bapak Buntaran, M.Si., Bapak Rusman, M.Si., dan Bapak Seme. Penelitian ini dibiayai oleh DIPA T.A. 2013.

\section{DAFTAR ACUAN}

Abreu, M.H., Varela, D.A., Henríquez, L., Villarroel, A., Yarish, C., Sousa-Pinto, I., \& Buschmann, A.H. 2009. Traditional vs. integrated multi-trophic aquaculture of Gracilaria chilensis C. J. Bird, J. McLachlan, \& E.C. Oliveira: Productivity and physiological performance. Aquaculture, 293: 211 220.

APHA (American Public Health Association). 2005. Standard methods for the examination of water and wastewater. $21^{\mathrm{st}}$ Edition. American Water Works Association (AWWA)/ American Public Works Association/Water Environment Federation. Washington, USA, $1,368 \mathrm{pp}$.

Barrington, K., Chopin, T., \& Robinson, S. 2009. Integrated multi-trophic aquaculture (IMTA) in marine temperate waters. In Soto, D. (Ed.). Integrated mariculture: a global review. FAO Fisheries and Aquaculture Technical Paper. No. 529. Rome, FAO. p. 7-46.

Beveridge, M.C.M. 1996. Cage aquaculture, $2^{\text {nd }}$ Ed. Blackwell Fishing News Books, Oxford, $346 \mathrm{pp}$.

BBL (Balai Budidaya Laut Lombok). 2012. Petunjuk teknis Budidaya Rumput Laut. Direktorat Jenderal Perikanan Budidaya, Kementerian Kelautan dan Perikanan.

Chopin, T., Buschmann, A.H., Halling, C., Troell, M., Kautsky, N., Neori, A., Kraemer, G., Zertuche-Gonzalez, J., Yarish, C., \& Neefus, C. 2001. Integrating seaweeds into aquaculture systems: a key towards sustainability. J. Phycol., 37: 975-986.

Costa-Pierce, B. 2008. An ecosystem approach to marine aquaculture: a global review. In Soto, D., Aguilar-Manjarrez, J., \& Hishamunda, N. (Eds.). Building an ecosystem approach to aquaculture. FAO Fisheries and Aquacul- 
ture Proceedings. No. 14. Rome, FAO. p. 81155.

Dawes, C.J. 1981. Marine botany. John Wiley and Sons, Inc. Canada, 628 pp.

DJPB (Direktorat Jenderal Perikanan Budidaya). 2012. Statistik perikanan budidaya Indonesia 2011. Kementerian Kelautan dan Perikanan. Jakarta, $116 \mathrm{hlm}$.

Effendi, H. 2003. Telaah kualitas air: bagi pengelolaan sumber daya dan lingkungan perairan. Kanisius. Yogyakarta, $258 \mathrm{hlm}$.

Effendie, M.I. 1979. Metode biologi perikanan. Cetakan pertama. Yayasan Dwi Sri. Bogor, $112 \mathrm{hlm}$.

Hanisak, M.D. 1983. The nitrogen relationships of marine macroalgae. In Carpenter, E.J. \& Capone, D.G. (Eds.). Nitrogen in The Marine Environment. New York. Academic Press. p. 699-730.

Hutardo, A.Q., Agbayani, R.F., Sanares, R., \& de Castro-Mallare, A.T.R. 2001. The seasonality and economic feasibility of cultivating Kappaphycus alvarezii in Panagatan Cays, Caluya, Antique, Philippines. Aquaculture, 199: 295-310.

KLH (Kementerian Lingkungan Hidup). 2004. Keputusan Menteri Negara Lingkungan Hidup No. 51 Tahun 2004 tentang Baku Mutu Air Laut.

KKP (Kementerian Kelautan dan Perikanan). 2012. Blue economy: Pembangunan kelautan dan perikanan berkelanjutan untuk kesejahteraan masyarakat (sustainabilitysocial inclusiveness-innovative investment). $32 \mathrm{hlm}$.

Loya, Y. \& Kramarsky-Winter, E. 2003. In situ eutrophication caused by fish farms in the northern Gulf of Eilat (Aqaba) is beneficial for its coral reefs: a critique. Mar. Ecol. Prog. Ser., 261: 299-303.

Neori, A. 2007. Essential role of seaweed cultivation in integratedmulti-trophic aquaculture farms for globalexpansion of mariculture: an analysis. J. Appl. Phycol., 20: 567570.

Neori, A., Spigel, M., \& Ben-Ezra, D. 2000. A sustainable integrated system for culture of fish, seaweed and abalone. Aquaculture, 186: 297-291.

Rachmansyah, Kaswadji, R.F., Bengen, D.G., \& Soedharma, D. 2004. Pendugaan laju sedimentasi dan dispersi limbah partikel organik dari budidaya bandeng dalam keramba jaring apung di laut. Aquacultura Indonesiana, 5: 91-101.

Radiarta, I N. \& Rasidi. 2012. Analisa spasial kondisi kualitas perairan untuk mendukung budidaya rumput laut di Teluk Gerupuk Kabupaten Lombok Tengah Provinsi Nusa Tenggara Barat. Prosiding Seminar Nasional Perikanan Indonesia 2012. Sekolah Tinggi Perikanan. Jakarta.

Radiarta, I N., Erlania, \& Rusman. 2013. Pengaruh iklim terhadap musim tanam rumput laut, Kappaphycus alvarezii, di Teluk Gerupuk, Kabupaten Lombok Tengah, Nusa Tenggara Barat. J. Ris. Akuakultur, 8(3): 453464.

Sanderson, J.C., Cromey, J., Dring, M.J., \& Kelly, M.S. 2008. Distribution of nutrients for seaweed cultivation around salmon cages at farm sites in north-west Scotland. Aquaculture, 278: 60-68.

Schlitzer, R. 2011 . Ocean data view. WWW Page. http://odv.awi.de.

Shi, H., Zheng, W., Zang, X., Zhu, M., \& Ding, D. 2013. Ecological-economic assessment of monoculture and integratde multitrophic aquaculture in Sanggou Bay of China. Aquaculture, 410-41 1: 172-178.

Troell, M., Halling, C., Nilsson, A., Buschmann, A.H., Kautsky, N., \& Kautsky, L. 1997. Integrated marine cultivation of Gracilaria chilensis (Gracilariales, Rhodophyta) and salmon cages for reduced environmental impact and increased economic output. Aquaculture, 156: 45-61.

Troell, M. 2009. Integrated marine and brackish-water aquaculture in tropical regions: research, implementation and prospects. In D. Soto (ed.). Integrated mariculture: a global review. FAO Fisheries and Aquaculture Technical Paper. No. 529. Rome, FAO. p. 47-131. 